\title{
A ÉTICA DA INCLUSÃO E AS FRONTEIRAS DA UNIDADE ${ }^{1}$
}

\author{
Maria Amélia Schmidt Dickie*
}

Resumo: Precisar lidar com as diferenças entre seus participantes tem sido um dos aspectos mais difíceis para os Conselho para o Ensino Religioso de Santa Catarina (CONER/SC), um grupo formado por diferentes religiōes, fundado em 1998 para assessorar o Estado de Sta Catarina na implementação do Ensino Religioso nas escolas públicas do estado. No processo de estabelecer uma identidade publica para o grupo, com a finalidade de legitimar seu status frente ao estado e aos professores de Ensino Religioso já atuantes, ele precisou lidar com as tensões provocadas pelas diferenças entre representantes cristãos de várias denominaçôes, católicas e protestantes (das quais só uma pentecostal), hinduísta, muçulmano e das religiōes afro-brasileiras. As estratégias usadas para evitar conflitos e produzir um discurso uníssono incluíram tanto o recurso ao silêncio em questôes delicadas quanto a discussão daquelas consideradas passiveis de uma abordagem não disruptiva. Este trabalho focaliza os valores éticos expressos mas nem sempre verbalizados durante este processo, bem como alguns dos desafios que a construção da unidade apresentou aos participantes do CONER/SC.

Palavras-chave: ensino religioso, ética da inclusão, macro-ecumenismo, religião e política.

\section{I}

O impacto que o Conselho para o Ensino Religioso de Santa Catarina (Coner/SC) me causou adveio de meu interesse anterior pelas relações entre política e religião e, mais diretamente, pelo inusitado deste aglomerado de múltiplas identidades religiosas assessorando o estado laico sobre ensino religioso. Em especial pelo fato de que, do ponto de vista do Estado, Religião deixava de ser um sujeito unívoco, como o foi na maior parte da historia do Estado no Brasil, para se apresentar multifacetado, um fenômeno da contemporaneidade brasileira. Em outro lugar (Dickie, 2003) detalhei o processo que construiu a identidade una através da qual o Coner se legitimou frente ao Estado e frente aos professores de ensino religioso já atuantes nas diferentes escolas (por iniciativa de suas igrejas e do Conselho de Igrejas para o Ensino Religioso de Sta. Catarina, de forte domínio

\footnotetext{
${ }^{1}$ Agradeço a Suzana Coutinho Bornholdt e Luciano Bornholdt a participação dedicada nos primeiros estágios desta pesquisa, com bolsas PIBIC/CNPq. A Emerson Giumbelli, Sandra Sá Carneiro e Janayna Lui, pela interlocução sempre instigadora.

* Programa de Pós-Graduação em Antropologia Social da Universidade Federal de Santa Catarina(UFSC).
} 
cristão católico). A construção da unidade se apoiou sobre a construção de uma identidade pública (Epstein, 1978) que a expressou, calcada sobre a noção de macro-ecumenismo. Agora quero penetrar um pouco mais a ética que orientou esta construção e expor os eventos que explicitaram os limites da unidade.

O primeiro encontro com o Conselho para o Ensino Religioso do Estado de Santa Catarina, o Coner-SC, foi motivado pela tentativa de respaldar a possibilidade de formados em Ciências Sociais, com habilitação em Antropologia, serem considerados aptos para serem professores de Ensino Religioso, no sistema educacional do Estado. Informados que a instância política que deveria ser abordada em primeiro lugar era o Coner, lá fomos, um colega antropólogo e eu, conversar sobre esta possível nova habilitação para nossos formandos. Nosso argumento central era o de que, estando igualmente distante de todas as religiōes, o Antropólogo (e a Antropologia) podia garantir uma isenção que não prejudicaria nenhuma religião, evitaria a veiculação de preconceito, em suma, daria uma informação sem viezes e não proselitista. A resposta que recebemos foi que isto não era aceitável. A razão: "queremos que o professor seja igualmente próximo da Religiāo".

A resposta recebida e o reconhecimento dos presentes à reunião do Coner/SC a que comparecemos deixou-me intrigada: lá estavam representantes da Igreja Católica Apostólica Romana, da Igreja Católica Apostólica Brasileira, da Igreja Evangélica de Confissão Luterana do Brasil, da Igreja Luterana do Brasil, da Igreja Metodista do Brasil, da Igreja Anglicana do Brasil, do Islā, da Fé Bahải e a única mulher representando as religiōes Afro-brasileiras². Integravam já o grupo que havia sido formado, por uma determinação legal, como assessor do estado na formulação dos programas e na implementação da disciplina Ensino Religioso, num modelo novo. A novidade vinha na Lei de Diretrizes e Bases da Educação de 1996, cujo artigo 33 fora modificado no ano seguinte para incluir Ensino Religioso como disciplina de oferecimento obrigatório pelas escolas públicas, facultativa para os alunos. O corpo docente tornou-se responsabilidade do estado, tanto quanto aos critérios para contratação, como na remuneração e inserção na carreira do magistério (Dickie, 2003; Lui, 2006; Giumbelli e Sa Carneiro, 2004, Fonaper 1998b) A lei instituía a formação de uma entidade civil pluridenominacional como interlocutora do estado para as questôes relativas ao novo modelo e exigia que o Ensino Religioso não fosse de cunho proselitista.

Formado em 1998, o Coner/SC estava em pleno processo de construção quando fizemos o primeiro contato. Tentava, através de discussões periódicas, atingir uma definição mais precisa de suas atribuiçôes, ao mesmo tempo em que tratava de compatibilizar a letra da lei com os desejos das "religiōes" presentes e tendo que lidar com os movimentos políticos do estado, a esta época resistindo em aceitar o Coner/SC como parceiro na questão do Ensino Religioso.

2 A Igreja do Evangelho Quadrangular fazia parte do Coner, nesta data, mas estava escolhendo novo representante. Por isto, nas primeiras reuniōes a que comparecemos, ela não estava presente. A Assembléia de Deus era membro oficial mas esteve ausente das reuniōes por quase um ano. A Igreja Vétero Católica começou a participar alguns meses depois do início da pesquisa.

Debates do NER, Porto Alegre, Ano 7, n. 10, P.113-124, Jul./DeZ. 2006 
Ecumenismo supõe a possibilidade de reconhecer nas religiōes incluídas um "mínimo de cristianismo". (Giumbelli, 2000) É este mínimo que permite, no trabalho ecumênico, o cruzamento de fronteiras denominacionais com poucas chances de risco. No esforço do Coner/SC de construiro que chamaram de "nosso macro-ecumenismo" um "mínimo de rel igião" tinha de ser reconhecido naqueles presentes e nos participantes prospectivos. Durante a campanha para aumentar o número de participantes, no inicio de sua atividade conjunta, o grupo enviou convites através do correio regular, para várias igrejas estabelecidas e também pra grupos como Seicho-No-Ie, espíritas da linhakardecista, um ashram, entre outros. O responsável pelo ashram aceitou o convite para participar do Coner/SC, inaugurando uma representação hinduísta no grupo. Representantes do Seicho-No-Iee do Espiritismo vieram a uma reuniāo e declinaram o convite por se considerarem filosofias e não religióes. O Coner/SC ficoubastante mobilizado por estas recusas. Mais do que pelas da Igreja dos Santos dos Últimos Dias e pelo silêncio de várias Igrejas neopentecostais. A recusa daquela foi compreendida por razões teológicas e o silêncio das segundas não foi interpretado como definitivo. Mas reconhecer a recusa do Seicho-No-Iee do Espiritismo de se rotularem como religiōes confrontou o Coner/SC com sua ignorância sobre os outros. A esta época, o Coner/SC tinharecebido um membro budista (e mais tarde um zen-budista) e o Seicho-No-Ie tinha sido catalogado na categoria geral das "religióes orien tais". Mas o importante aqui é menos o desconhecimento Coner/SC sobre os outros do que a vontade de reconhecer religião nos grupos que se consideravam filosofias.

Este evento leva a um ponto importante. Religião foi concebida por todos os membros do Coner/SC como um aspecto da natureza do ser humano. Ao naturalizar a religião, o Coner/SC reconheceu nela a relação substantiva de cada ser humano (portanto de cada participante ou participante prospectivo do Coner/SC) com a divindade definida por ele/ela. Esta definição inclusiva de religião teve conseqüências não só no estabelecimento de uma ética de aceitação do outro diferente, o que estou chamando de ética da inclusão-express a na auto-definição do Coner/SC como um gr upo macro-eaumênico - mas para a própria definição do propósito de ter Ensino Religioso na escola, como detalharei abaixo. E é baseada nesta concepção do Coner/SC que, daqui para frente, vou me referir aos indivíduos participantes no grupo como "religião" - a que eles, de alguma forma representam, utilizan do os mesmo "ismos" por eles utilizados. Dito de outra forma, os participantes serão referidos através da categoria adscritiva pela qual eles reconheciam (e reconhecem) uns nos outros, religiāo. Esta categoria teve o efeito explicito de nivelar todos os participantes.

Por um ano, os três diretores do Coner/SC mantiveram reuniōes com funcionárias da Secretaria de Educação de Santa Catarina, reuniôes para as quais eram convidados professores dos Cursos Magister de Ciências da Religião e alguns teólogos, a maioria Católicos Romanos. As reuniōes foram realizadas em sala da Secretaria de Educação e discutiram duas questôes em profundidade: o propósito do Ensino Religioso nas escolas públicas e o conteúdo desta disciplina nos diferentes níveis de ensino. Ainda que as funcionárias da Secretaria de Educação fossem muito favoráveis à inclusão do Ensino Religioso nos currículos escolares, tendo com o ER um compromisso de consciência, elas frequentemente mencionavam serem minoria nos quadros funcionais e não terem o apoio incondicional

Debates do NER, Porto Alegre, ANo 7, n. 10, P. 113-124, jul./Dez. 2006 
da Secretária. Sugeriam, através destas observaçóes, com as quais pontuavam seus discursos, e outras sobre mudanças na estrutura do sistema de ensino do estado que ocorria naquele momento, que um boicote silencioso à plena implementação do Ensino Religioso era sempre uma possibilidade presente. Assim, a discussão sobre o propósito do ER era também a construção de sua justificativa frente a forças políticas adversas, o que definiu o processo de consolidação do Coner/SC como um campo de luta (Dickie, 2003). Nestas discussões, duas perspectivas eram claramente diferentes - a antropocêntrica e a teocêntrica.

Para participar destas reuniōes na Secretaria de Educação, o Coner/SC havia feito e (continuava fazendo) reuniōes mensais entre seus membros e tinha conseguido chegar a um consenso sobre a definição da finalidade do Ensino Religioso (e, concomitantemente, a justificativa da ação do Coner/SC), depois de uma longa e forte discussão argumentativa que colocou o Islã e o Luteranismo (nas duas vertentes) de um lado, contra todos os outros. E esta era a perspectiva da dupla mencionada, muito inspirada pelo misticismo sufi do Islã: o ensino religioso deveria ser dado a alunos das escolas públicas para propiciar sua relação com Deus, qualquer que fosse o nome a Ele/Ela dado. A esta perspectiva chamaram de "teocêntrica". A perspectiva oposta, dentro do Coner/SC, a que foi rotulada de "antropocêntrica", pensava o en sino religioso como um meio de recuperar valores fundamentais para a relação entre os seres humanos. Os conceitos de irmandade, justiça social e igualdade de direitos sustentavam esta perspectiva, muito em consonância com a Teologia da Libertação e os prinćpios pós Vaticano II. Esta era, também, a perspectiva das funcionarias da Secretaria de Educação e do Governador do Estado, um dos incentivadores da cooperação entre o Coner/SC e a Secretaria de Educação.

A perspectiva defendida pela Afro-brasileira, sacerdotiza de Candomblé e ativista negra, também abraçava estes princípios, identificando-se, mais facilmente, com a idéia de direitos e justiça social neste mundo do que com a perspectiva misticamente inspirada que privilegiava a idéia de um Deus e a definição do ser humano por sua vinculação com Ele. O Budismo esteve ausente desta discussão mas não contestou diretamente seus resultados. Os Luteranismos, que desde o primeiro momento seguiram a perspectiva que prevaleceu, deram-se conta, antes dos outros, de que a generalidade dela era o caminho mais promissor para a unidade do Coner/SC. Os demais finalmente concordaram que, sim, o que subjazia a todos os credos ou fés era a relação de Deus com os humanos, aceitando assim que a possibilidade da existência do grupo e sua ação repousava no que anteriormente chamei de "mínimo de religião", definindo, assim, sua medida.

$\mathrm{O}$ argumento que se provou crucial na perspectiva "teocêntrica" foi o da necessidade de expressar uma diferença entre Ensino Religioso e História das Religiōes, só possível se a relação Deus/Humanos fosse privilegiada no primeiro. Assim, apesar de numericamente minoritária, a perspectiva "teocêntrica" venceu e foi estabelecida como a do Coner/SC. Este argumento vitorioso encontrou resistência tênue na medida em que, simultaneamente, formulou, veiculou e reforçou, sem nunca o ter mencionado, o critério mais fundamental da inclusão e, portanto, da identidade pública do grupo. No final desta discussão foi definido o que veio a ser referido posteriormente como o Princípio do Coner/SC, definido também como o fundamento da atuação do grupo em relação ao Ensino Religioso e, portanto, aquele que o Coner/SC deveria insistir estivesse presente nos conteúdos programados para os diferentes níveis escolares. Foi assim redigido:

Debates do NER, Porto Alegre, Ano 7, n. 10, P.113-124, Jul./DeZ. 2006 
As Tradições Religiosas receberam a revelação de que o ser humano chega a sua plenitude na medida em que ele se reintegra a Deus, ao Absoluto, ao Pai Maior, à Mãe Terra, ao Transcendente... As hipóteses científicas que vêm oferecendo várias explicações da gênese deste princípio não podem ser privilegiadas, conforme o mais correto espírito científico. Em razão disto, é imprescindível que o Ensino Religioso oportunize o conhecimento que as diversas Tradições Religiosas detêm do caminho da reintegração. (Reunião do ConerSC, 20 julho 2000)

Este texto mostra o alcance das preocupações do grupo com a inclusão. Que uma visão etnocêntrica estava embutida na própria idéia de um Deus, uno e criador, ou não foi percebida ou foi intencionalmente ignorada, especialmente por aquelas religióes que não a tem como eixo de seus credos, ou, posto de forma mais geral, de suas cosmologias. Foi, no entanto, iniciativa daquelas religiôes que haviam formulado a proposição vencedora que os vários e diferentes nomes de Deus, nas diferentes Tradições Religiosas, fossem incluídos no Princípio do Coner/SC. Como todas concordaram com a impossibilidade de exaurir estes nomes, também concordaram que as reticências deveriam estar no texto para representar o número incomensurável das possibilidades concretas. Junto com estabelecer a primazia das relações Deus-Humanos para o ER, o Princípio contemplaria, com isto, a diversidade histórica das manifestações de Deus através do conceito complementar de Tradições Religiosas.

A ética da inclusão relevou na definição do Princípio, a presença efetiva ou participação formal de religiōes no Coner/SC. Ainda que a questão da participação formal estivesse em discussão muitas vezes (e voltarei a isto adiante), ao formular o Princípio e ao decidir pela inclusão dos muitos nomes de Deus, o grupo concordou sobre a necessidade de incluir uma referência às religiōes indígenas brasileiras e a fez através da expressão "Mãe Terra". Nenhum indígen a havia estado nas reuniōes ou fora contatado, apesar de algumas esporádicas referências sobre a necessidade de sua inclusão. A propriedade (no sentido da correção) da categoria adscritiva nunca foi testada.

Uma outra questão foi levantada na formulação do Princípio, no que dizia respeito a sua adequa-ção aos ditames da lei, e era sobre o caráter necessariamente não proselitista que devia revestir o Ensino Religioso. Esta foi uma questão quente para os membros do Coner/SC, em duas "frentes". Se não con seguissem ass egurar à Secretaria de Ed ucação que o Principio respeitava esta prescrição, perderiam, de antemão, a legitimidade que estavam tentando garantir. Se não conseguissem assegurar uns aos outros que nenhuma das religiões teria um espaço maior que a outra, cairiam no cadafalso da competição interna. Era importante deixar claro, uns aos outros, que Ensino Religioso não era uma questão de “propagan da” de uma ou outra religiāo. A unidade construída pelo Principio do Coner/SC tinha de garantir a não-competição entre as religiōes presentes. Elas trataram da questão do proselitismo através de duas perguntas: 1 . Ensino Religioso deveria ter um caráter descritivo ou valorativo? 2. Se, como diz o Principio, a reintegração a Deus é um valor, como falar dele e não ser proselitista?

A resposta foi encontrada na definição de proselitismo muito própria do Coner/SC, cuja base está na naturalização da religião: proselitismo seria o ato de induzir alguém na

Debates do NER, Porto Alegre, ANo 7, n. 10, P. 113-124, jul./Dez. 2006 
direção de uma determinada doutrina religiosa ${ }^{3}$. Assim, Ensino Religioso, enquan to propagador de Deus como o "começo ao quais os humanos devem retornar", não seria proselitista, na medida em que a cada religião fosse garantido o espaço para ensinar o caminho a ela revelado deste retorno ou reintegração. E esta garantia estava no Principio. Como outras questôes não foram levantadas sobre conceitos sensíveis, como o de revelação, por exemplo, o grupo conseguiu alcançar uma convergência.

$\mathrm{Se}$, ao atuar de acordo com a ética da inclusão o Coner/SC produziu um relativismo que era novo entre religióes no Brasil, ao definir a relação entre valor e proselitismo declarou seus limites: o valor da vida como o retorno a Deus é a verdade absoluta sobre a qual seu argumento repousa. Disto decorreu o entendimento, pelo grupo, de que os professores de Ensino Religioso tinham de ter uma religiāo. Um ateu, disseram, não poderia jamais defender um principio religioso.

É preciso salientar que questôes de fé religiosa não são critérios legais para a escolha de professores, nem mesmo de Ensino Religioso. Neste caso, o critério é ter um diploma de Ciências da Religião. O Coner/SC não pareceu se preocupar com este requisito aparentemente ilegal e que não teriam a capacidade de fazer valer. No entanto, no curto prazo, o requisito estaria sendo respeitado uma vez que todos os alunos dos cursos de Ciências da Religião eram religiosos - a maioria tinha estado atu ando como professores in dicados por suas igrejas antes da aprovação da nova lei.

No longo prazo a probabilidade do cenário permanecer o mesmo é alta, pois todos os professores destes cursos de graduação estão ligados a igrejas ${ }^{4}$. Mais importante, as religiões participantes no Coner/SC tem estimulado seus afiliados a se formarem em Ciências da Religião para poderem se candidatar a um contrato no Sistema Estadual de Ensino. Portanto, as ações do Coner/SC foram permeadas pela quase certeza de que todos os professores de Ensino Religioso seriam religiosos, tal como nos havia sido afirmado no primeiro encontro. Mas esta quase certeza significou que ao mesmo tempo em que o Coner/SC podia contar com o compromisso dos professores com a religião, tinha de convencê-los a aplicar o Principio do Coner/SC como base de sua pedagogia e isto passava igualmente pelo gerenciamento pedagógico do Estado e dos cursos de Ciências da Religião. Em ambas instancias prevalecia a perspect iva "an tropocêntrica".

Uma crítica latente sobre a separação Estado/Religião estava presente todo o tempo, seja no discurso do Islã, mais predizível, seja no do Catolicismo Romano. Uma clara luta

3 Participei de uma reunião entre o Conselho Diretor e a Secretária da Educação. Foi uma reunião política, uma vez que sua finalidade era fazer pressão sobre a Secretaria para que implementasse Coordenadores Regionais de Ensino Religioso no sistema escolar. Num dado momento, os Diretores do Coner/SC asseguraram a ela que o ER que propunham não era proselitista. Ela sorriu e respondeu que, no seu entender, religião era proselitista, e não devia se impor à esfera de ação governamental. Foi o que provocou o Coner/SC a encontrar sua própria definição.

4 É de conhecimento geral que a maioria dos graduados nestes cursos são pessoas comprometidas com alguma religião. Em 1999 e 2000, só um professor dos quatro cursos de Ciências da Religião, no estado de Santa Catarina, era um antropólogo sem filiação religiosa. Entre os outros, a grande maioria eram teólogos da Igreja Católica Apostólica Romana.

Debates do NER, Porto Alegre, Ano 7, n. 10, P.113-124, Jul./DeZ. 2006 
para a legitimação da Religião com ou "dentro" do Estado também permeava a racionalidade do trabalho e do esforço do Coner/SC para construir uma identidade que fosse aceita publicamente como aquela da Religião.

\section{III}

A ética da inclusão foi desafiada em várias ocasiōes. Classificarei estes desafios em duas categorias provisórias, internos e externos, e vou iniciar com os primeiros.

Ao mesmo tempo em que o Coner/SC (através dos anos, até agora) tem insistentemente convidado novos participantes, duas questôes interrelacionadas e que dizem respeito à estrutura do Coner/SC foram objetos privilegiados de discussão. A da "representação" e a da contribuição pecuniária devida por cada partiaipantepara garantir o funcionamento do Coner/ SC (secretaria, papel, um escritório, etc. $)^{5}$. A questão da representação teve de responder às perguntas "quem tem o dir eito de estar aqui?"; "O participante precisa ser nomeado por ma igreja, credo ou culto?”; "É necessário que ele/ela esteja representando (no sentido democrático) um corpo de fieis?"; "Ou deveria ele estar representando uma religiāo?". A resposta encontrada nivelou a todos. O Coner/SC aceitaria todos os que pudessem ser incluídos na sua definição de Religião. A importância da representação não era a da "representação democrática", mas a da "represen tação da religiāo". Se a religião fosse institucionalizada, a sanção da instituição religiosa era bem-vinda e uma questão de respeito. Mas, como no caso das religióes Afro-brasileiras, com institucionalização frouxa ou quase nenhuma, a referência institucional não seria necessária. Aqui a ética da inclusão privilegiou, coerentemente, a Religião sobre o de laço institucional, no grupo "macro-ecumênico". Tanto assim que qualquer dos participantes era e é elegível para cargos de diretoria.

No entanto, a questão da contribuição pecuniária deu origem a uma situação mais delicada. As discussões sobre ela iniciaram no âmbito da Diretoria e resultaram na decisão de que uma contribuição de $\mathrm{R} \$ 100,00$ deveria ser dada, mensalmente, por cada participante. Quando trazida ao grupo maior, a quantia foi questionada como muito elevada por muitos dos Cristãos presentes, que também contribuíam com o CIER, a maioria com orçamentos estreitos. A quantia foi reduzida à metade. Mas alguns participantes declararam a total impossibilidade de contribuir. A participante Afro-brasileira declarou que não tinha instituição para bancar o pagamento e não tinha condições de fazê-lo pessoalmente. $\mathrm{O}$ argumento Budista foi de outra natureza: ele alegou que, quando convidado a fazer parte do Coner/SC, este era para ser um Conselho, isto é, um provedor de aconselhamento para o Estado. No entanto, o Coner/SC havia se tornado uma instituição em defesa do

5 Durante os dois primeiros anos o Coner/SC compartilhou escritório e secretario com o CIER. Os membros do Coner/SC queriam se dissociar do CIER, um grupo reconhecido como cristão. De 2001 em diante as reuniōes do Coner/SC são realizadas numa sala da Secretaria de Educação e tem um secretario voluntário dentre seus membros. As despesas foram reduzidas a um mínimo e a correspondência tem sido feita pela Internet, através de computadores da Igreja a qual o Secretario está filiado.

Debates do NER, Porto Alegre, ano 7, N. 10, P. 113-124, Jul./DeZ. 2006 
Ensino Religioso. Ao demandar dinheiro dos participantes para que pudesse defender seus interesses o Coner/SC se tornava totalmente incompatível com a visão Budista do Ensino Religioso. Assim, seria mais adequado para o Budismo não participar mais do Coner/SC. Um interessante diálogo ocorreu neste momento, o qual reproduzo abaixo como ilustração dos debates entre os membros do Coner/SC e da clareza das posiçóes expressas:

Islã (ao Budismo): Você não defenderia ataques ao Budismo? Onde fica a compaixão? Compaixão por um ignorante sem mover um dedo para ajudá-lo... qual é o valor disto?

Luteranismo: Nós mudamos nosso Estatuto de grupo para instituição. O Budismo vê as coisas diferente.

Catolicismo Romano: Posso ver o fundamento religioso de tua posição. Mas minha pergunta é qual a diferença entre grupo e instituição? Nós nos tornamos uma instituição e mantivemos a mesma finalidade de controle.

Budismo: Esta é a posição de meu grupo. Não nega outras. Um conselho só existe por que alguém quer ser aconselhado. Este deveria assumir a responsabilidade pelo custo. Eu virei aqui quando perguntas específicas forem feitas ao Budismo.

Islã e Luteranismo: Mas há ignorância. A criança quer saber mas o mediador (o estado) não permite.

Budismo: Se alguém não quer saber, nós não dizemos. A criança, se quiser saber, pode me chamar e eu falo. Nos temos uma webpage.

Islã: $\mathrm{O}$ ato de compaixão precisa de um posicionamento ativo. $\mathrm{O}$ que fazer com alguém que não sabe e por causa disto não tem condições de perguntar?

Budismo: Ele espera até que chegue sua hora.

A posição do Budismo e o não pagamento por parte da Afro-brasileira confrontavam o Coner/SC com a iminência de perder dois membros não cristãos, fatores legitimadores do seu auto-atribuído macro-ecumenismo. Encontrou duas soluções. Os que não podiam pagar permaneceriam como membros regulares e teriam seus débitos perdoados. Havia provisão nos Estatutos para este caso. O Budismo e outros que tivessem posição similar permaneceriam como convidados especiais esporádicos e deixariam de constar da lista de participantes regulares.

Vale notar que somente o Budismo viu a contribuição pecuniária como uma monetarização da participação no Coner/SC e produto de uma mudança na sua natureza. Ainda que o montante proposto fosse contestado, nenhum outro participante contestou o fato de que algo devia ser dado como contribuição. Tiveram uma visão pragmática da questão, não desafiando a lógica político/econômica subjacente de que a autonomia e independência do grupo dependiam também da sua possibilidade de se auto-financiar.

Os desafios externos à unidade não se referem, aqui, a ataques sofridos pelo Coner/ SC, mas a conflitos que ou estavam ocorrendo ou surgiram, entre religiōes, fora das fronteiras do grupo. Como regra, o reconhecimento destes conflitos foi evitado sistematicamente

Debates do NER, Porto Alegre, Ano 7, n. 10, P.113-124, Jul./DeZ. 2006 
pelo Coner/SC. Por exemplo, a critica constitucional dos pentecostalismos àqueles que "adoram imagens" ou sua cond enação das religiōes Afro-brasileiras como demoníacas. Mesmo as animosidades históricas como as existentes entre o Islã e a Fé Bahải foram contornadas pelo silêncio. Eventualmente uma situação mais tensa entre os participantes, por qualquer razão, se dissolvia através do mecanismo da jocosidade que dava conta de manter o diálogo e era aceito por todos. De fato, fazer piadas e rir frente algumas das mais aparentes características do outro foi uma forma muito eficiente de lidar com os diversos graus de tensão e de resolver diferenças num plano não conflitivo.

A eficiência relativa destes mecanis mos - o silêncio e a jocosidade - tem sua origem na própria definição de religião do Coner/SC. Esta definição permitiu aos participantes tratar um ao outro como religião e colocar as individualidades numa posição subaltema. De tal forma que as características individuais (a sofisticação intelectual, o discurso agressivo, o gênero, por exemplo) não eram reconhecidas no discurso verbal. Este foi sempre de religião para religiāo, ainda que a linguagem corporal possa ter enviado uma mensagem diferente e as expressões faciais mostrassem sentimentos. Invariavelmente, no entanto, estas outras formas de discurso eram como que tamponadas pelo discurso verbal entre religiōes, o que salientava, da ética da inclusão e da definição de religião, o respeito pelas diferentes Tradições Religiosas. A possibilidade de este procedimento ser mantido definiu as fronteiras do Coner/SC.

Um eventoinesperado serviu de gatilho para a exclusão da religião Afro-brasileira quando o Coner/SC entendeu as açóes de sua representante como de natureza individualista. Tomei conhecimento deste evento através de um e-mail da Afro-brasileira enviado a uma lista de pessoas vinculadas ao ativismo negro ou religioso (de diversas origens). Era um protesto contra um documento emitido pelo Conselho Episcopal da Igreja Metodista, condenando as religiōes Afro-brasileiras como não-religiosas e maléficas que estavamcirculando pela Internet, endereçado, primordialmente, aos filiados à Igreja Metodista. Num tom moralizador, o documento urgia os receptores a formar grupos de discussão que, "sob a ótica do Reino de Deus", analisasse os programas veiculados pela TV, em es pecial quan to à evidência dada neles à cultura afro-brasileira em geral, em especial à valorização de aspectos considerados imorais, contrários aos preceitos bíblicos (como por exemplo, a dança, os oráculos, o comportamento sexual, etc.). Na mensagem de protesto, a Afro-brasileira argumentou sobre o erro do documentometodista, fundando-se em dois pontos legitimadores: a dramáticarealidadeda diáspora Africana e a rica especificidade da cultura Afro-brasileira, de um lado; de outro, a realidade do Coner/SC e o princípio sob o qual o Ensino Religioso estava sendo implementado como um sinal dos novos tempos de convivência das diferentes religiōes e servindo de base para um macro-ecumenismo respeitoso da diversidade. Sua assinatura trazia referências ao seu status de membro da Diretoria do Coner/SC e membro de um grupo ativista negro.

Contrariando as expectativas da Afro-brasileira, as fronteiras da unidade do Coner/ $\mathrm{SC}$ se provaram estreitas. Na avaliação de alguns de seus membros, o documento era de um fundamentalismo exagerado e, apesar de considerarem que a questão que sua publicação colocava deveria ser discutida pelas religiōes, ela não era de imediata pertinência para o Coner/SC, pois não dizia respeito ao Ensino Religioso. Por outro, a reação da Afrobrasileira estaria mais calcada na sua militância negra do que nas questôes religiosas. Em conseqüência desta recusa de apoio do Coner/SC, a representante Afro-brasileira deixou o

Debates do NER, Porto Alegre, ano 7, N. 10, P. 113-124, Jul./DeZ. 2006 
grupo. Do seu ponto de vista, o Coner/SC não poderia ter se abstido de uma declaração pública, sendo uma instância de macro-ecumenismo e tendo no grupo representantes das duas religiōes deflagradas. Não foi possível saber mais sobre este episódio, por parte do Coner/SC, além do que relatei acima. Ninguém do grupo quis falar muito sobre o assunto, descartando-o como de menor importância para o Ensino Religioso. A saída oficial da representante Afro-brasileira foi verbalmente lamentada, mas não parece ter havido nenhum esforço para trazer outra/o Afro-brasileira/o para o Coner/SC. E tanto quanto me foi possível saber, o pastor Metodista participante nunca foi confrontado com a questão.

A participação das religiōes no Coner/SC teve e tem como substrato ao menos três perspectivas diferentes. Uma, especialmente verdadeira, no caso das "religiōes minoritárias" (incluindo aqui algumas cristãs menos conhecidas ou relativamente novas no Brasil), a de que uma versão correta de suas religiões fosse ensinada nas escolas. Um corolário desta perspectiva é a tentativa de evitar que Ensino Religioso permanecesse como uma prática catequética da Igreja Católica Romana. Preocupavam-se de perder a oportunidade que este espaço público das escolas oferecia para difundir a informação correta. Outra explícita no discurso do Islã, dos Luteranismos e do Catolicismo Romano, a de que a Religião fosse conduzida a uma posição de proeminência legítima na sociedade. E outra que operava com o reconhecimento público de uma religiāo especifica como Religiāo. O exemplo mais evidente desta perspectiva é o caso das religiōes Afro-brasileiras que, tradicionalmente atuam nas estruturas não oficiais de poder e, ao mesmo tempo, são alvo de discriminação por parte de outras religiōes. (Brown, 1994; Prandi, 1991). Mas algumas igrejas cristãs também partilham desta expectativa ${ }^{6}$.

A ética da inclusão e as fronteiras da unidade do Coner/SC refletem, como que num micro-cosmos, os limites da igualdade entre religiōes. Apesar dos esforços das "religiōes minoritárias" para conquistar espaço na esfera pública e do fato de que atualmente ocupam cargos na diretoria do Coner/SC, nos últimos cinco anos o grupo reconheceu a importância de ter o Catolicismo Romano ou os Luteranismos nestas posiçóes. Sua capacidade de negociação com o estado e suas condiçóes de diálogo com os professores foram reconhecidas como melhores e se provaram mais eficientes. Este reconhecimento, estratégico, provou-se realista.

Em 2006, a lei estadual que complementa a regulamentação da lei federal sobre Ensino Religioso passou na Assembléia Legislativa do Estado. O Coner/SC foi a éminance grise por trás do texto da lei, tendo trabalhado, ombro a ombro com as funcionárias da Secretaria de Educação na elaboração do texto legal. Desde 2002 as reuniōes do Coner/SC acontecem numa sala da Secretaria de Educação. Considerando a simbólica do espaço,

6 Mais recentemente duas igrejas se uniram ao Coner/SC: A Igreja Católica Apostólica Syriana e a Igreja Católica Apostólica Missionáriade Evangelização, ambas originárias do Estado de Santa Catarina. 7 Os Luteranismos e o Catolicismo Romano ocuparam o cargo de presidente durante a maior parte do tempo de existência do Coner/SC. O Hinduismo teve um mandato.

Debates do NER, Porto Alegre, ANo 7, n. 10, P.113-124, Jul./DEZ. 2006 
poder-se-ia dizer que hoje o Coner/SC atua com o Estado e de dentro dele, sugerindo o que Giumbelli (2000) chamou de intersecção de domínios, uma configuração que nada de novo tem na história brasileira, apesar de sua ordem republicana. Um aspecto significativo desta intersecção agora é que a Religiāo se apresenta com múltiplas faces. No entanto, se há a legitimidade explícita do universo múltiplo da Religião, a hegemonia do Catolicismo Romano (secundada por uma posição historicamente legítima no estado dos Luteranismos) é perfeitamente percebida pelas outras religiōes. No caso do Estado de Santa Catarina, as pessoas que, no governo, atuam em favor do Ensino Religioso nas escolas públicas são católicas. Assim são a maioria dos professores que eram voluntários, antes de 1998, e que agora estão sendo formados por cursos (Magister, no início, atualmente cursos regulares) de Ciências da Religião para poderem integrar o quadro estadual de professores.

A atuação do Coner/SC continua sob a égide da ética da inclusão. A aceitação de pequenas ou novas igrejas é bem vista. As recentes boas vindas dadas a um sacerdote de Candomblé e sua esposa sacerdotisa não permitem ainda maior elaboração. Chegaram por iniciativa própria e seu discurso apoiou a decisão de participar no Coner/SC na prática inclusiva do grupo. Querem contribuir com sua própria atividade enquanto fundadores de uma Universidade das Religióes Afro-brasileiras. Mas, na avaliação que hoje faço, a ética da inclusão aparece como predominantemente estratégica, tanto para a construção da identidade pública que permitiu ao Coner/SCa legitimaçáo do Ensino Religioso e, portanto, da Religião no espaço público, quanto para as religióes participantes que buscam integrar este espaço. Por este limite, a ética da inclusão talvez não consiga transbordar as fronteiras do grupo, nem da direção que pretende: o Ensino Religioso. Esta avaliação precisa ser testada junto aos professores da rede estadual para saber se o Coner/SC teve algum sucesso ao disseminar para a pedagogia destes atores a ética da inclusão, ou se o Ensino Religioso ainda estará sendo oferecido numa base catequética e proselitista, no sentido definido pelo Coner/SC.

\section{REFERÊNCIAS}

AZZI, R. 1986. A Igreja no regime republicano. In Religiāo e Sociedade 13/3:76-92.

BERGER, P. 1973. The social reality of religion. Inglaterra: Penguin

BECKFORD, J. e T. LUCKMANN. 1991. The changing face of religion. Inglaterra: Sage Publications

BOURDIEU, P. 1974. A economia das trocas simbólicas. S. Paulo: Perspectiva.

BROWN, Diana. 1994. Umbanda - Religion and politics in urban Brazil. N.York: Columbia University Press.

CARON, Lurdes. 1997. Entre conquistas e concessôes: uma experiência ecumênica em Educação Religiosa Escolar. S.Leopoldo: Ed.Sinodal.

DELLA CAVA, Ralph. 1980. Fontes para o Estudo do Catolicismo e Sociedade no Brasil. In Religião e Sociedade, 5:211-240. 
DELLA GIUSTINA, Elias.s/dAs novas exigênciasdo EnsinoReligioso. Encontros Teológicos. Tubarão. DICKIE, M.A.S. 2003. Todos os caminhos levam a Deus: o Coner e o ensino religioso em Sta. Catarina. GT Religião e Sociedade, 27․ Encontro Anual da ANPOCS, Caxambu.

DICKIE, M.A.S. e LUI, Janayna A. 2005. O ensino religioso e a interpretação da lei. GT Religião,poder e política. XIII Jornadas sobre Alternativas Religiosas na América Latina. PUC-RS, Porto Alegre.

EPSTEIN, E. L. 1978. Ethos and identity. Londres: Tavistock Publications.

FIGUEIREDO, Anísia de P. 1994. Ensino religioso: perspectivas pedagógicas. Petrópolis: Vozes. FONAPER, 1998a. Capacitação docente - licenciatura - lato sensu - Extensão para o ensino religioso. Fórum Nacional Permanente de Ensino Religioso.

FONAPER, 1998b. Parâmetros curriculares nacionais - Ensino Religioso. Editora Ave-Maria. FRESTON, Paul. 1998. Evangelicals and politics: a comparison between Africa and Latin America. In Journal of Contemporary Religion, 13:1, pp.37-50.

GIUMBELLI, Emerson. 2000. O fim da religião. Tese de doutorado, Museu Nacional UFRJ. GIUMBELLI, E. \& S. SA CARNEIRO. 2004. Ensino religioso no Estado do Rio de Janeiro - Registros e controvérsias. Comunicações do ISER, n.60.

GRUEN, W. 1984. Aspectos legais do Ensino Religioso na escola. in. Revista de Educação AEC, ano 13, n.51. Brasília, pp.52-61.

GRUEN, W.1994. O ensino religioso na escola. Petrópolis: Vozes.

HOONRNAERT, Eduardo et alli. 1979. História da Igreja no Brasil. Ensaio de interpretação a partir do povo. Petrópolis: Vozes.

KLUG, J. 1998. Confessionalidade e etnicidade em Sta. Catarina - tensões entre luteranos e católicos. in Revista de Ciências Humanas. n.24. pp.111-127.

LUI, Janayna A. 2006. Emnome de Deus-um estudo sobre a implementação do Ensino Religioso nas escolas publicas do Estado de São Paulo. Dissertação de Mestrado, PPGAS/UFSC.

MANHĀES, L.C.L. 1996. Estrutura e funcionamento do ensino: legislação básica para $1^{\circ}$ e $2^{\circ}$. graus. Florianópolis: Ed. Da UFSC.

PRANDI, R. 1991. Os candomblés de São Paulo. S.Paulo: Hucitec.

ROMANO, Roberto. 1979. Brasil: Igreja contra o Estado. S.Paulo: Kairós.

SANTOS, S.C. dos. 1998. Nova história de Santa Catarina. Florianópolis: Terceiro Milênio.

SANTOS, S.C. dos. 1963. Educação e desenvolvimento em Sta. Catarina. Florianópolis. Ed. Da UFSC.

SAVIANI, Demerval. Política e educação no Brasil. Campinas: Autores Associados.

SCAMPINI, José ,SDB. 1978 A liberdade religiosa nas constituiçôes brasileiras - Estudo filosófico jurídico comparado. Petrópolis: Vozes.

Secretaria de Educação de Sta. Catarina. 1998. Proposta curricular de Sta. Catarina, Ensino Médio e Fundamental.

Debates do NER, Porto Alegre, Ano 7, n. 10, P.113-124, Jul./DeZ. 2006 